\title{
IS THE CAPITAL STRUCTURE STABLE IN BRAZIL?
}

\author{
PÂMELA A. TRISTÃO ${ }^{1}$ \\ (iD) https://orcid.org/0000-0002-8408-6942 \\ IGOR B. SONZA \\ (iD) https://orcid.org/0000-0001-5403-3279
}

To cite this paper: Tristão, P. A., \& Sonza, I. B. (2019). Is the capital structure stable in Brazil? Revista de Administração Mackenzie, 20(4). doi:10.1590/1678-6971/eRAMF190154

Submission: Oct. 6, 2018. Acceptance: Jan. 31, 2019.

1 Universidade Federal de Santa Maria (UFSM), Santa Maria, RS, Brazil.

\section{(cc) BY




\section{ABSTRACT}

Purpose: This paper's objective is to analyze whether the capital structure of Brazilian publicly traded companies remained stable over the last twenty years.

Originality/value: The paper is focused on the Brazilian capital market, in which there is a lack in the literature about the study of the leverage behavior and its immaturity, where factors related to the companies and characteristics in contracting leverage alter the demand of credit.

Design/methodology/approach: To achieve its objective, initially a graphical analysis of market and book debt evolution was carried out, and a GMM-Sys regression model through panel data was estimated to identify the stability of leverage along time.

Findings: The results indicate a reduction of the market leverage with higher statistical significance after 2008, indicating, both in the graphic and the regression analysis, that the use of debt was unstable in the first period analyzed (1995-2007), behavior not observed during the second period (2008-2015) when analyzed market measures in which capital structure stability was prevalent, with considerable reduction of corporate leverage, otherwise, book measures of leverage would have shown a stability trend in leverage patterns. The principal determinants of the capital structure were the tax benefits (book debt) and the size (market debt), supporting trade-off theory.

\section{KEYWORDS}

Capital structure. Trade-off theory. Pecking order theory. Leverage. Stability. 


\section{INTRODUCTION}

The firm's capital structure consists of the long-term financing resources (equity capital or debt) a company uses to invest in projects. The mix of financing sources allows for companies with different debt ratios. Devos, Rahman, and Tsang (2017) state that studies in this topic tried to find a suitable debt ratio adjustment to reach an optimal capital structure. The search for the optimal capital structure originated many studies with the objective of identifying the best combination of financing sources or characteristics that interfere in this decision.

Studies initiated with the seminal paper by Modigliani and Miller $(1958,1963)$ stating about the irrelevance of the capital structure. Contrary to this, by the trade-off theory, there is an optimal combination of debt and equity, which can equilibrate tax benefits and the distress costs; otherwise, according to the pecking order theory assumptions, companies might prefer internal to external resources due to the presence of asymmetric information (Myers, 1984).

Although studies related to this theme have enriched the understanding about capital structure choices, Denis (2012) argues that they do not explain enough the decisions about capital structure because is not related to the factors that influenced the higher or lower need of capital. For Graham, Leary, and Roberts (2015), after years since the beginning of the interest about this theme, there are still many doubts about this decision, allowing new researches to be carrying it out. Recent studies focused on the analysis of issuing debt and factors related to it, testing the hypothesis of capital structure stability (Lemmon, Roberts, \& Zender, 2008; De Angelo \& Roll, 2015).

For De Angelo and Roll (2015), the capital structure stability is considered a critical feature of corporate financial policy, so, if leverage ratios exhibit only modest variation, the studies should focus on identifying timeinvariant determinants of capital structure. Otherwise, if stability is pervasive, the investment and growth opportunities are probably essential components of the financial policy.

Based on the Brazilian stock market, its characteristics, the influence of companies' characteristics, as well as variables like tax rates, financial crisis and capital injection of investors, the aim of this study is to analyze if the capital structure of Brazilian companies has shown a stable behavior over the last 20 years.

Although there are plenty of studies about capital structure, the motivation for this paper is its behavior. For Graham, Leary, and Roberts (2015), 
there is an increasing interest of researchers to focus their studies on the changes in debt ratios choices and the capital structure behavior by identifying the attributes that influence in it, such as taxes, asymmetric information, corporate governance rules and investment opportunities.

In this perspective, Lemmon et al. (2008), when studying the stability hypothesis, confirmed a stable behavior for a sample of US companies over 40 years. They found that companies with high debt ratios tend to keep them, as well as, companies whose use of debt is low, face the tendency not to issue more debt. In contrast, De Angelo and Roll (2015) found the opposite, whose results evidenced an unstable behavior, showing that the fixed effects' behavior found by Lemmon et al. (2008) are not persistent, prevailing the instability.

By the contradictory results mentioned and the particularities of the Brazilian capital market, this study is justified by three main reasons. The first is linked to the lack in the literature about the study of leverage behavior, as the majority of studies related to capital structure in Brazil aim to test theories' assumptions, but do not focus on the access to capital. The second refers to stock market immaturity in Brazil, where factors related to companies and characteristics in contracting leverage may alter the granting of credit. The last one refers to methodological terms; the Generalized Method of Moments System (GMM-Sys) was used in the regressions, generating more robust results for the analysis.

\section{THEORIES OF CAPITAL STRUCTURE AND THE RECENT NEW APPROACHES}

The study about capital structure has gained distinction through the paper considered a mark in the theme, written by Modigliani and Miller (MM, 1958), who conclude for the inexistence of an optimal capital structure. According to them, if the firm keeps the free cash flow distribution constant, the financing policy chosen is irrelevant. The MM theory contradicts the trade-off idea that, if the cost of debt is less expensive than equity and have tax benefits, firms should use higher levels of debt until an optimal point, when firms start to face bankruptcy costs by the use of high debt ratios (Kraus \& Litzenberger, 1973).

Although accepted, the trade-off theory and its assumptions did not answer questions related to firms' characteristics and their influence in financing decisions, which led the literature to focus on firm's specific problems, such as the level of information asymmetry. Based on different levels of information, the pecking order theory, proposed by Myers and 
Majluf (1984) and Myers (1984) defend a hierarchy in the use of capital to finance projects in which a firm should choose internal founds first, by the use of retained earnings. If necessary, firms could use external sources, issuing debt and, finally, stocks. In this way, firms should issue debt as a first external source and, issue stocks only if equity and debt are not enough.

The hierarchy proposed by the pecking order theory is based on the asymmetric information involved when agents evaluate the need for external sources by the company. According to Myers (1984), the preference for internal capital is based on the possibility to reduce or extinguish the problems related to adverse selection, based on the existence of asymmetric information. Contrary, by issuing new stocks, the company can dilute the ownership of stakeholders and involve problems related to different information between internal and external agents that could not evaluate correctly the company's assets and, therefore, price them at a medium value, as argued by Akerlof (1970).

Although the trade-off and the pecking order are considered the most relevant theories in this theme, which have being tested internationally (Shyam-Sunder \& Myers, 1999; Fama \& French, 2002; Frank \& Goyal, 2009; Leary \& Roberts, 2005; Lemmon et al., 2008; Serrasqueiro \& Caetano, 2015) and nationally (Brito \& Lima, 2005; Iquiapaza, Souza, \& Amaral; 2007; Medeiros \& Daher, 2008), these analysis have been expanded in recent years. According to Taratin Jr. and Valle (2015), studies started to incorporate external factors that influence the company's financing mix.

This new research line presupposes that not only the company's attributes influence the financing choice, but also factors related to firms' capital need, the offer of financial resources and particularities of each economy. Studies have been focusing on the behavior of leverage to distinguish the heterogeneity of the capital structure observed. Some of them have focused on the influence of historical aspects in the actual capital structure (Baker \& Wurgler, 2002; Kayhan \& Titman, 2007) and the companies' responses in a capital sock (Alti, 2005; Flannery \& Rangan, 2005; Leary \& Roberts, 2005).

Lemmon et al. (2008) point out the necessity to discuss other approaches in the capital structure. To do so, they examined the leverage evolution in a sample of firms listed in Compustat between 1965 and 2003, analyzing its effects for the capital structure, as well as comparing their results to previous ones in the literature. In general, their results showed a variation in capital structures that is primarily determined by factors that remain stable for long periods; showing two characteristics unexplained by previous control variables (size, profitability, market-to-book, industry) and changes in sample composition. 
For Lemmon et al. (2008) the empirical knowledge acquired about the capital structure was more limited than they thought, as their results showed that the majority of variation is time-invariant and the existing models for capital structure do not recognize part of this variation. Because of their results, new researches aiming to analyze leverage behavior by testing the stability hypothesis have been done.

According to De Angello and Roll (2015), the leverage stability found by some studies (Graham, Harvey, \& Puri, 2009; Hennessy, Livdan, \& Miranda, 2010; Malmendier, Tate, \& Yan, 2011) can be considered an exception, which has been wrongly accepted by the academy. The authors made this statement by finding that in a sample of firms that covers 60 years of analysis; companies did not show debt ratios close to the average ratio over the entire period. In addition, when analyzing graphically the leverage behavior of 24 companies, relevant peaks of high and low leverage could be found along the time.

In contrast to the Lemmon et al. (2008) findings, De Angello and Roll (2015) defended the instability hypothesis, based on three arguments: 1. stability refers to the situation in which the average debt of a company remains in a narrow range; 2 . the mean stability means that the expected value of leverage remains constant throughout time, not in some periods; and 3. transversal stability refers to the situation where future leverage distributions resemble the cross-sectional distribution.

Apart from studies that confirm a stable or unstable behavior, Graham, Leary, and Roberts (2015) found both tendencies when analyzing companies listed in the American Stock Exchange (Amex), The New York Stock Exchange (NYSE) and The National Association of Securities Dealers Automated Quotation (Nasdaq). Their results showed, in the early years, a stable behavior with a tendency in companies' debt ratio over time, differently, the last years showed peaks in debt financing, characterizing instability.

\section{METHODOLOGICAL ASPECTS}

The sample consists of Brazilian listed companies traded on Bolsa, Brasil, Balcão (B3) and covers an analysis over 20 years, from 1995 to 2015. It is worth stating that, companies whose assets are canceled were included in the sample, as well as the ones which had their assets available for at least five years in the period analyzed and companies listed nowadays with information for, at least, five years as well. The sample was divided into two parts in order to analyze the evolution of the capital structure. 
The first one (P2) contemplates 2,325 observations from 1995 to 2007 and the second (P1) contemplates 1,719 observations from 2008 to 2015. This division is justified by the fact that, through graphic analysis, a period of greater stability was verified after 2008, probably due to the financial crisis. The data was collected by Economatica from companies' balance sheet, income statement, and other financial reports. Financial and insurance firms were excluded. The values were adjusted for inflation using the General Price Index - Internal Availability (IGP-DI), converted in US dollars and performed by using Stata SE software.

To test the hypothesis of the capital structure stability, a non-balanced Panel Data by a Systemic Generalized Method of Moments (GMM-Sys by Blundell \& Bond, 1998) with the dynamic model was chosen, in which the dependent variable lagged can be used as an explanatory variable. For Ozkan (2001), this model allows the inclusion of firms' specific effects and dummies over time, furthermore is considered an efficient method to control endogeneity.

To conduct the analysis, the following tests were applied: 1 . the correlation test; 2. the Arellano and Bond (1991) test, to identify the existence of serial correlation; 3. the over-identification test by Hansen (1982); and 4. chi-square. Equation 1 shows the model proposed:

$$
E_{i t}=\alpha_{i}+E_{i t-n} \beta+Z_{i t} y+C_{i t} \delta+\sum_{i}^{n} \text { EFind }_{i}+\sum_{t}^{n} \text { Eftemp }_{t}+\varepsilon_{i t}
$$

where $\mathrm{E}$ represents the capital structure of a firm; $\alpha$ is the intercept; $y, \beta$ and $\delta$ are the coefficients of the variables; $Z_{i t}$ are the explanatory variables; $C_{i t}$ are the control variables; EFind represents industry fixed effects; EFtemp the temporal fixed effects; and $\varepsilon_{i t}$ the error term.

As mentioned before, the papers of Lemmon et al. (2008), De Angelo and Roll (2015) and Graham et al. (2015) emphasize the study of capital structure behavior. In order to analyze the leverage ratios stability hypothesis of Brazilian companies, the variables measured by them were adapted. As proposed in their study, the dependent variables are representative of the firms' capital structure, as shown in Figure 3.1. 


\section{(Figure 3.1)}

\section{DEPENDENT VARIABLES}

\begin{tabular}{|c|c|c|}
\hline Variable & Code & Measure \\
\hline Total market debt & TLM & $\begin{array}{l}\text { (Current liabilities + non-current liabilities)/market value of } \\
\text { assets }\end{array}$ \\
\hline Total book debt & TLA & $\begin{array}{l}\text { (Current liabilities + non-current liabilities)/book value of } \\
\text { assets }\end{array}$ \\
\hline Long-term market debt & LLM & Non-current liabilities/market value of assets \\
\hline Long-term book debt & LLA & Non-current liabilities/book value of assets \\
\hline \multicolumn{3}{|c|}{$\begin{array}{l}\text { Note: it was used the concept of Chung and Pruitt (1994) to measure the market value of assets, which consider } \\
\text { (MVE + PS + D), where MVE is the product of the firm's share price and the number of common shares outstanding } \\
\text { PS is the settlement value of preferred shares outstanding and D is the total debt. Total debt is calculated a } \\
\text { follows: } D=P C \text { - AC + E + DLP, where PC is current liabilities, AC is current assets, E is the inventory, and DLP is th } \\
\text { long-term debt. }\end{array}$} \\
\hline
\end{tabular}

Apart from the dependent variables shown, the independent variables used in this study are intended to explain the capital structure hypothesis of stability. To identify the leverage behavior, the dependent variables were lagged in one, two and three years, while estimating the model, that, for Nakamura, Martin, and Forte (2007) can be considered a measure for capital structure adjustment speed towards the optimal debt ratio.

Apart from identifying the influence of previous debt ratio in the current levels of debt, control variables were added in the model, which according to Axelson, Jenkinson, Strömberg, and Weisbach (2013), are considered relevant when studying the analysis of the leverage capacity of a given company, as presented in Figure 3.2.

\section{(Figure 3.2)}

\section{EXPLANATORY AND CONTROL VARIABLES}

\begin{tabular}{cccccc}
\hline \multicolumn{1}{c}{ Variable } & Code & Measure & Previous studies & POT TOT \\
\hline Return on assets & ROA & $\begin{array}{l}\text { Operating income }(1-\text { tax }) / \\
\text { Total assets }\end{array}$ & Frank and Goyal (2009) & - & + \\
\hline Return on equity & ROE & Net income/Equity & Frank and Goyal (2009) & - & + \\
\hline
\end{tabular}




\section{(Figure 3.2 (conclusion))}

\section{EXPLANATORY AND CONTROL VARIABLES}

\begin{tabular}{|c|c|c|c|c|c|}
\hline Variable & Code & Measure & Previous studies & POT & TOT \\
\hline Free cash flow & $\mathrm{FCL}$ & $\begin{array}{l}{[\text { EBITx }(1-\text { Tax })+\text { depreciation- }} \\
\text { Capex]/Total assets }\end{array}$ & $\begin{array}{l}\text { Kim and Sorensen (1986) } \\
\text { and Keefe and Yaghoubi } \\
(2016)\end{array}$ & - & + \\
\hline Dividends & DIV & Dividends paid/Net income & Frank and Goyal (2009) & + & - \\
\hline \multicolumn{6}{|c|}{ Firm size } \\
\hline Total assets & LTA & Log of assets & $\begin{array}{l}\text { Lemmon et al. (2008), } \\
\text { Frank and Goyal (2003), } \\
\text { and Sonza and Kloeckner } \\
\text { (2014) }\end{array}$ & & + \\
\hline Net sales & $L R$ & Log of net sales & $\begin{array}{l}\text { Frank and Goyal (2003) } \\
\text { and Sonza and Kloeckner } \\
(2014)\end{array}$ & & + \\
\hline Equity & $L P L$ & Log of equity & $\begin{array}{l}\text { Sonza and Kloeckner } \\
(2014)\end{array}$ & & + \\
\hline Mature firms & Mat & $\begin{array}{l}\text { Dummy: } 1 \text { - companies that } \\
\text { traded in the stock market at } \\
\text { least five years } 0 \text { - otherwise }\end{array}$ & Frank and Goyal (2009) & & + \\
\hline \multicolumn{6}{|c|}{ Growth opportunities } \\
\hline $\begin{array}{l}\text { Market-to-book } \\
\text { ratio }\end{array}$ & MB & Market value/Equity & $\begin{array}{l}\text { Frank and Goyal (2009) } \\
\text { and Lemmon et al. (2008) }\end{array}$ & - & \\
\hline $\begin{array}{l}\text { Change in log } \\
\text { assets }\end{array}$ & LMA & $\begin{array}{l}\text { Log of (total assets - total } \\
\text { assets t- } 1 \text { ) }\end{array}$ & Frank and Goyal (2009) & & + \\
\hline Capex & Capex & $\begin{array}{l}\text { Capital expenditure/Total } \\
\text { assets }\end{array}$ & $\begin{array}{l}\text { Frank and Goyal (2009) } \\
\text { and Axelson et al. (2013) }\end{array}$ & + & \\
\hline Q Tobin & Q & Market value/Total assets & $\begin{array}{l}\text { Futema, Basso, and Kayo } \\
\text { (2009) }\end{array}$ & - & \\
\hline \multicolumn{6}{|c|}{ Nature of assets } \\
\hline Tangibility & Tang & $\begin{array}{l}\text { (Inventories + fixed assets)/ } \\
\text { Total assets }\end{array}$ & $\begin{array}{l}\text { Kieschnick and Moussawi } \\
\text { (2018) and Lemmon et al. } \\
\text { (2008) }\end{array}$ & & + \\
\hline \multicolumn{6}{|c|}{ Tax } \\
\hline Tax benefits & $\mathrm{BF}$ & $\begin{array}{l}\text { Tax }=\text { Income tax } \times \text { Financial } \\
\text { expenditure/Total assets }\end{array}$ & $\begin{array}{l}\text { Frank and Goyal (2009) } \\
\text { and Lemmon et al. (2008) }\end{array}$ & & + \\
\hline \multicolumn{6}{|c|}{ Risk } \\
\hline Risk & RIS & $\begin{array}{l}\text { Standard error of EBIT/Total } \\
\text { assets }\end{array}$ & $\begin{array}{l}\text { Frank and Goyal (2009) } \\
\text { and Lemmon et al. (2008) }\end{array}$ & + & - \\
\hline
\end{tabular}

Note: POT = pecking order theory; TOT = trade-off theory.

Source: Elaborated by the authors. 


\section{ANALYSIS OF RESULTS}

This subsection aims to identify the behavior of Brazilian capital structure over a twenty-year period (1995-2015). Three steps conduct the analysis. The first consists of graphical analysis of leverage for a sample median. Secondly, the descriptive statistics and correlation test, to finally discuss the estimation model and robustness tests.

The graphical analysis aims to show a tendency in leverage by the use of debt of Brazilian companies. Figure 4.1 shows graphically the leverage median of companies in the sample, which can indicate a tendency in terms of leverage. As stated by Titman and Wessels (1988), the use of book and market measures for leverage as the dependent variable is justified by the possibility of separating the effects of the capital structure suggested by the literature.

The book measures (TLA and LLA) showed a tendency of companies to maintain leverage levels over the twenty years in the majority of companies, which characterizes the stability hypothesis of capital structure behavior. The graphical analysis follows international patterns in observing capital structure behavior in recent years, allowing the comparison of results. The result is similar to that of Lemmon et al. (2008), who defended the capital structure stability as their results show that firms with relatively high leverage tend to maintain this pattern.

Contrary, when observed leverage related to market value (TLM and LLM), a standard characteristic in companies' leverage was pointed out by the sharp fluctuations in debt ratios in the first 13 years (1995-2007) and its reduction in the last ones. As observed, due to peaks of low and high leverage, the first period evidences instability in capital structure by showing fluctuations in debt. In contrast, the second period shows a less unstable capital structure. This evidence of periods with instability and stability of the capital structure was documented by Graham, Leary, and Roberts (2015) in US firms, but in a different order (as their results state a stable behavior in the first period, followed by an unstable pattern). Figure 4.2 presents the leverage level used by eight established companies from different economic segments that had the information for all the 20 years analyzed. 


\section{(Figure 4.1)}

\section{LEVERAGE RATIOS GRAPHICAL ANALYSIS}

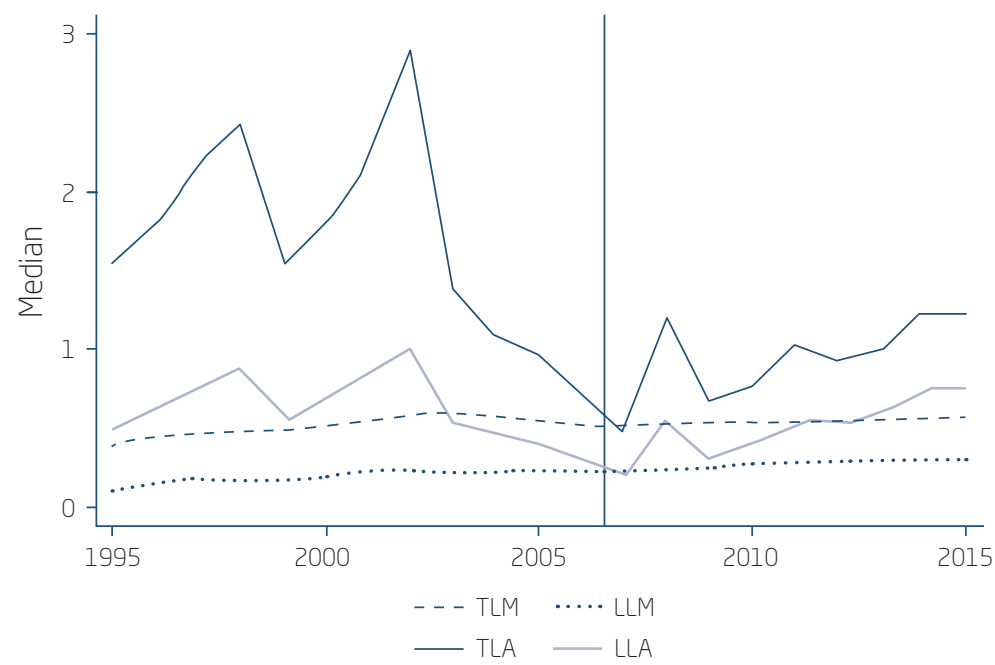

Source: Elaborated by the authors.

\section{(Figure 4.2)}

\section{LEVERAGE RATIOS GRAPHICAL ANALYSIS BY SECTOR}
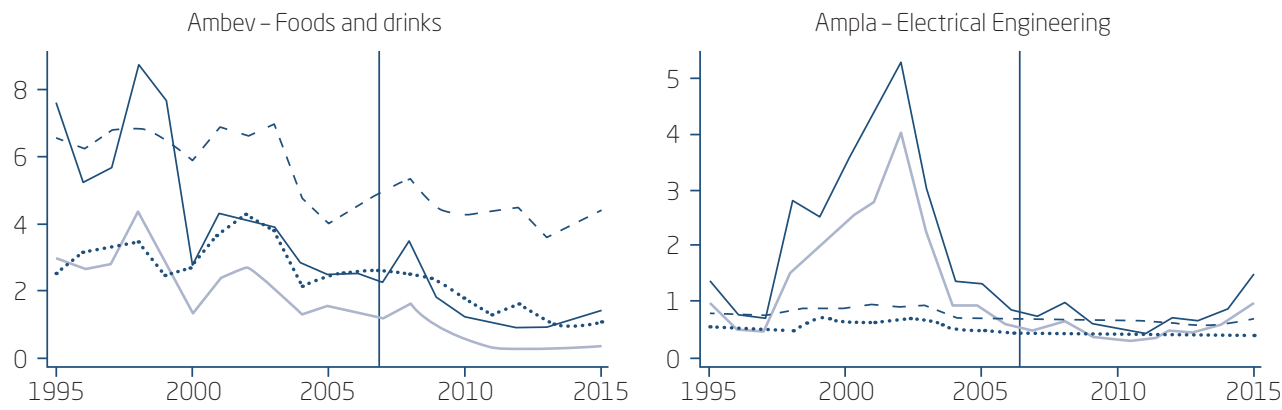

$\begin{array}{ll}--- \text { TLM } & \cdots \cdot \ln L \mathrm{LL} \\ - \text { TLA } & - \text { LLA }\end{array}$

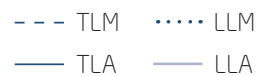

(continue) 


\section{(Figure 4.2 (conclusion))}

\section{LEVERAGE RATIOS GRAPHICAL ANALYSIS BY SECTOR}
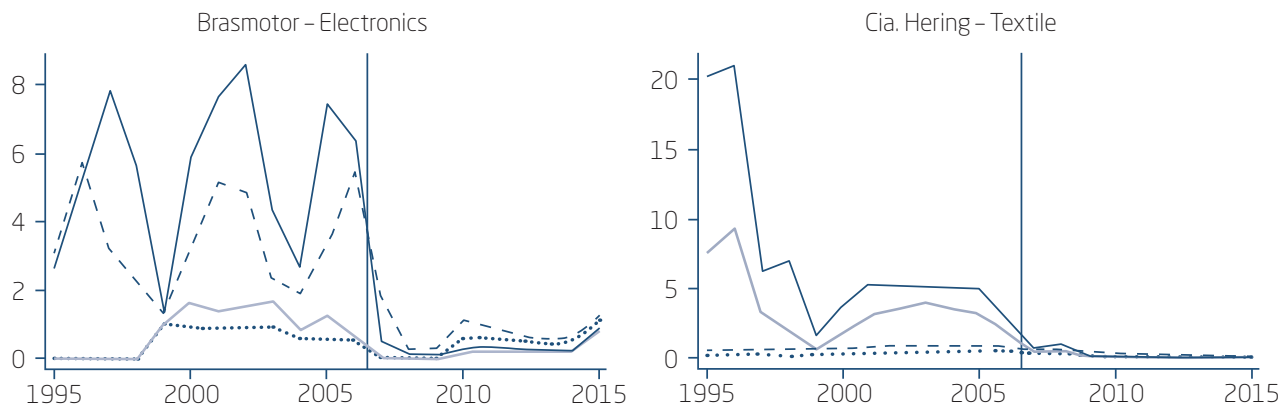

Elequeiroz - Chemistry
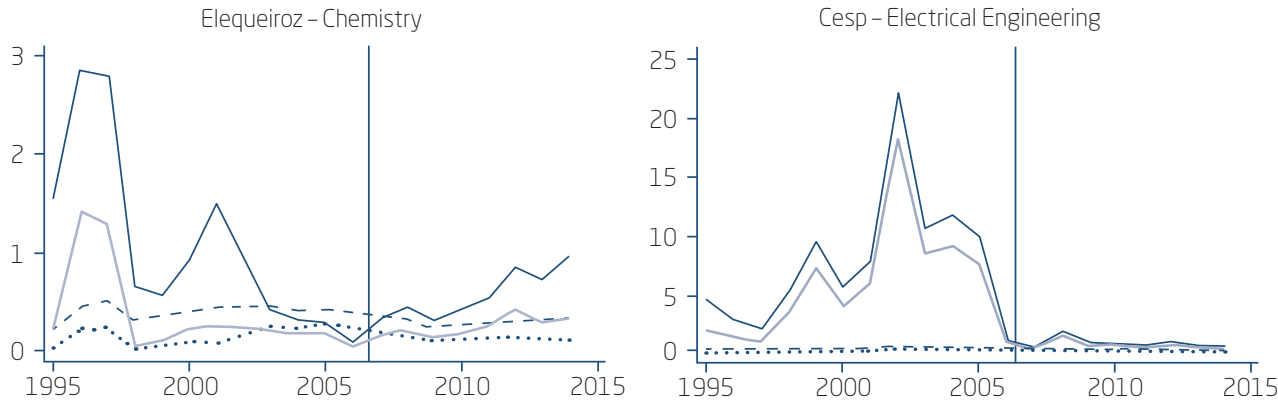

Lojas Americanas - Commerce
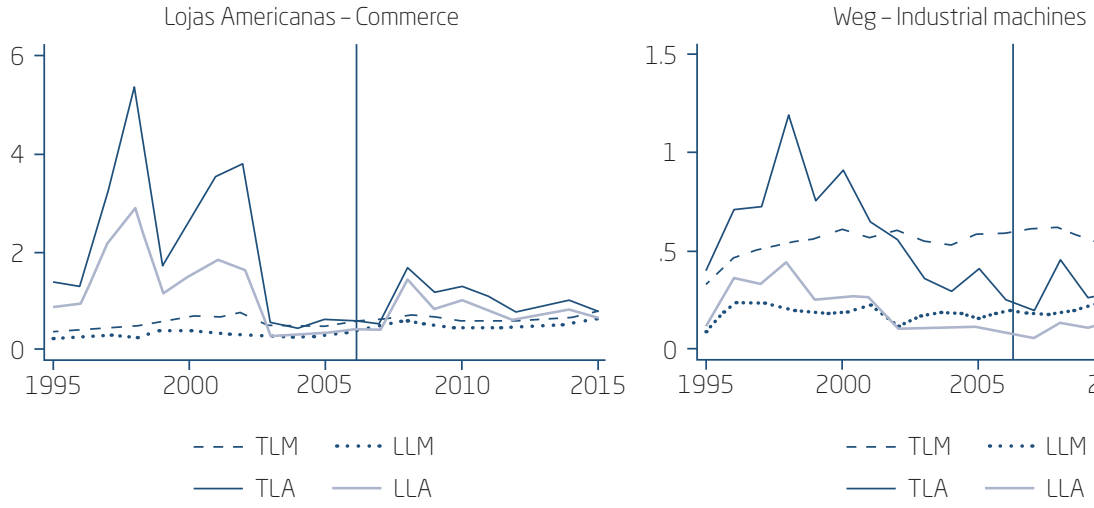

Source: Elaborated by the authors 
It could be observed that, from 2008 to 2015, companies used less leverage and this evidence can be directly associated to the Subprime Financial Crisis, initiated in the mid-2000s in North America, which became a world financial crisis and influenced financial market internationally. This crisis influenced negatively financial aspects and economic growth, reducing access to credit and currency devaluation in emerging countries, such as Brazil. The supply of resources in recession was impacted directly by the companies' choice for capital and, consequently, the credit offered by lenders (Tarantin Junior \& Valle, 2015).

As stated by Ferreira and Mattos (2012), the effects of the international financial crisis in Brazilian capital market are related to increased risk aversion and preference for liquidity by foreign investors, causing a suddenly increased uncertainty in the Brazilian economy.

This fact influenced the lower level of the external fund used by companies in the second analyzed period, which, due to the risk scenario, reduced their investments. They argue that the world financial market oscillations led to a volatility increase and, consequently, a fall in the prices of Brazilian assets.

To conduct the next step, which consists in the analysis of variables used in the model, variables were winsorized at the level of $5 \%$ to reduce the outliers. Figures 4.3 and 4.4 show the descriptive statistics. The data analyzed, from 1995 to 2015, has been divided into two periods, which has been made based on the behavior of leverage measures shown graphically in Figure 4.1. The sample was divided into P2, from 1995 to 2007, and P1, from 2008 to 2015.

It is possible to observe that, when analyzed the sample referring to P2, the majority of variables were close to the median, with exception of the total assets, net sales, and equity, indicating the necessity to apply logarithm in these variables. When analyzing the market performance, on average, the market value of companies exceeds $34 \%$ its equity and represents $56 \%$ of the total assets. The inventories and fixed assets are approximately $38 \%$ of the total assets and the companies use, on average, $7 \%$ of the Capex. ROA and ROE are, on average, $2 \%$ and $-1 \%$.

The total assets are, on average, US\$ 1.5 billion, the net sales represent US $\$ 0.77$ billion and the equity is US $\$ 0.53$ billion. The risk related to the EBIT represents $6 \%$ of the total assets, and the free float is, on average, negative, representing $3 \%$ of the total assets. The dividends paid represent $45 \%$ of the net income and the change in the assets represent US\$ 11.13 million. Finally, the tax benefit represents $6 \%$ of total assets. 


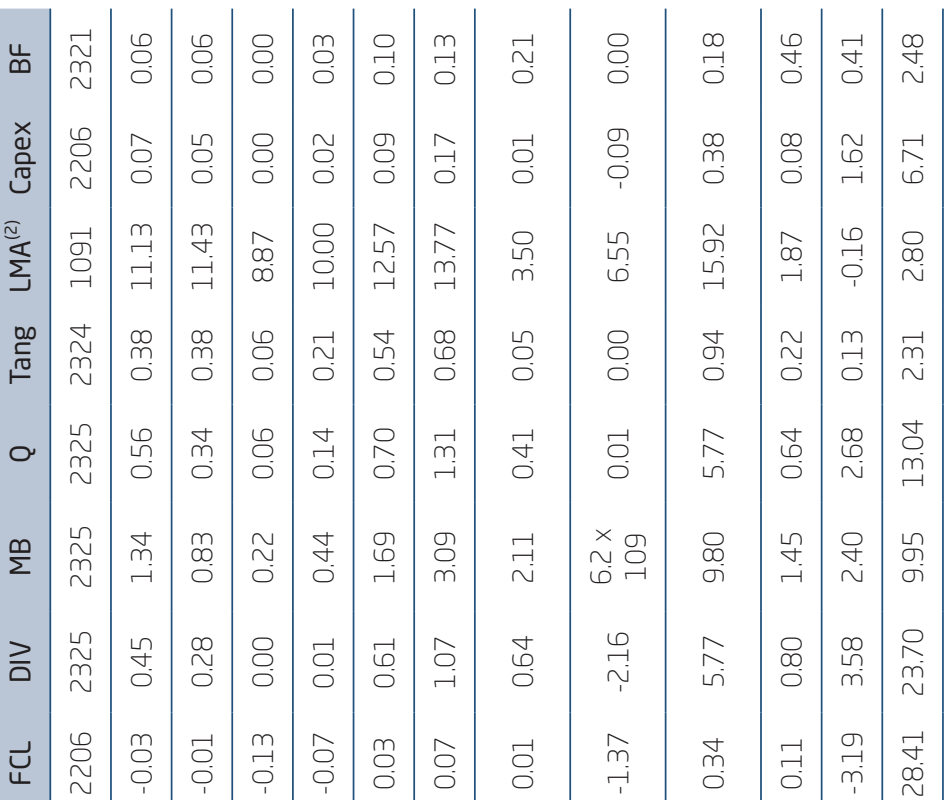

口

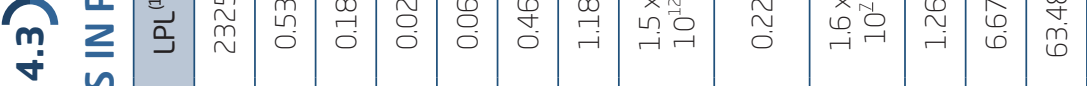

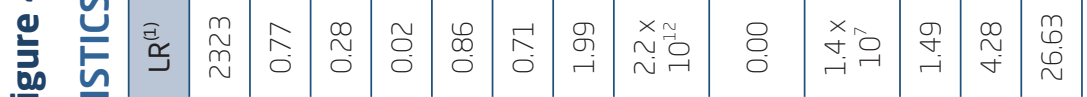

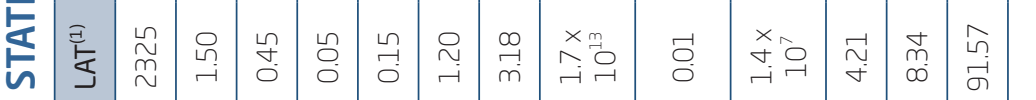

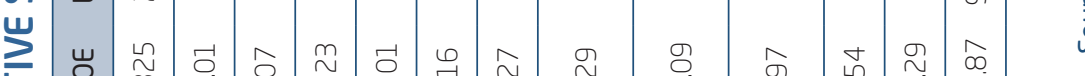

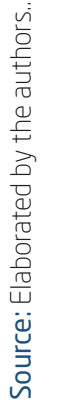

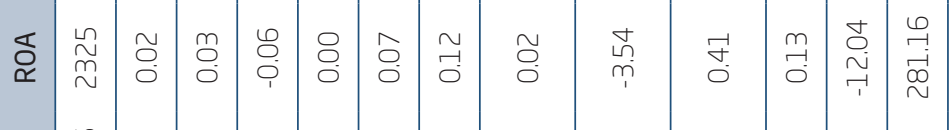

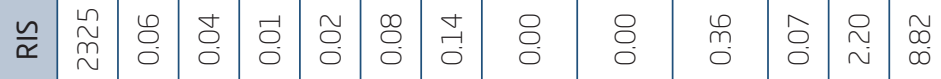

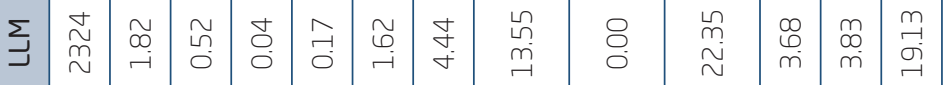

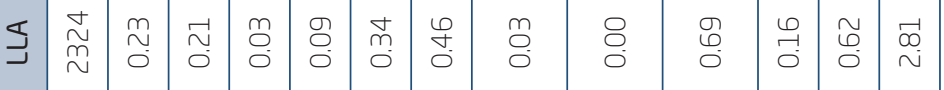

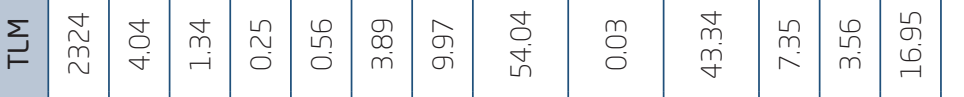

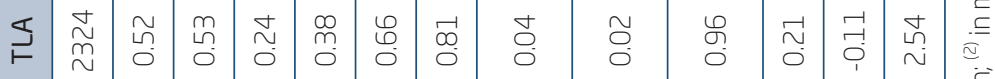

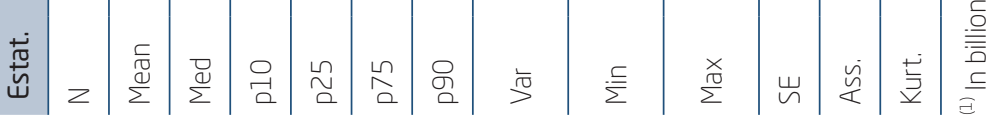




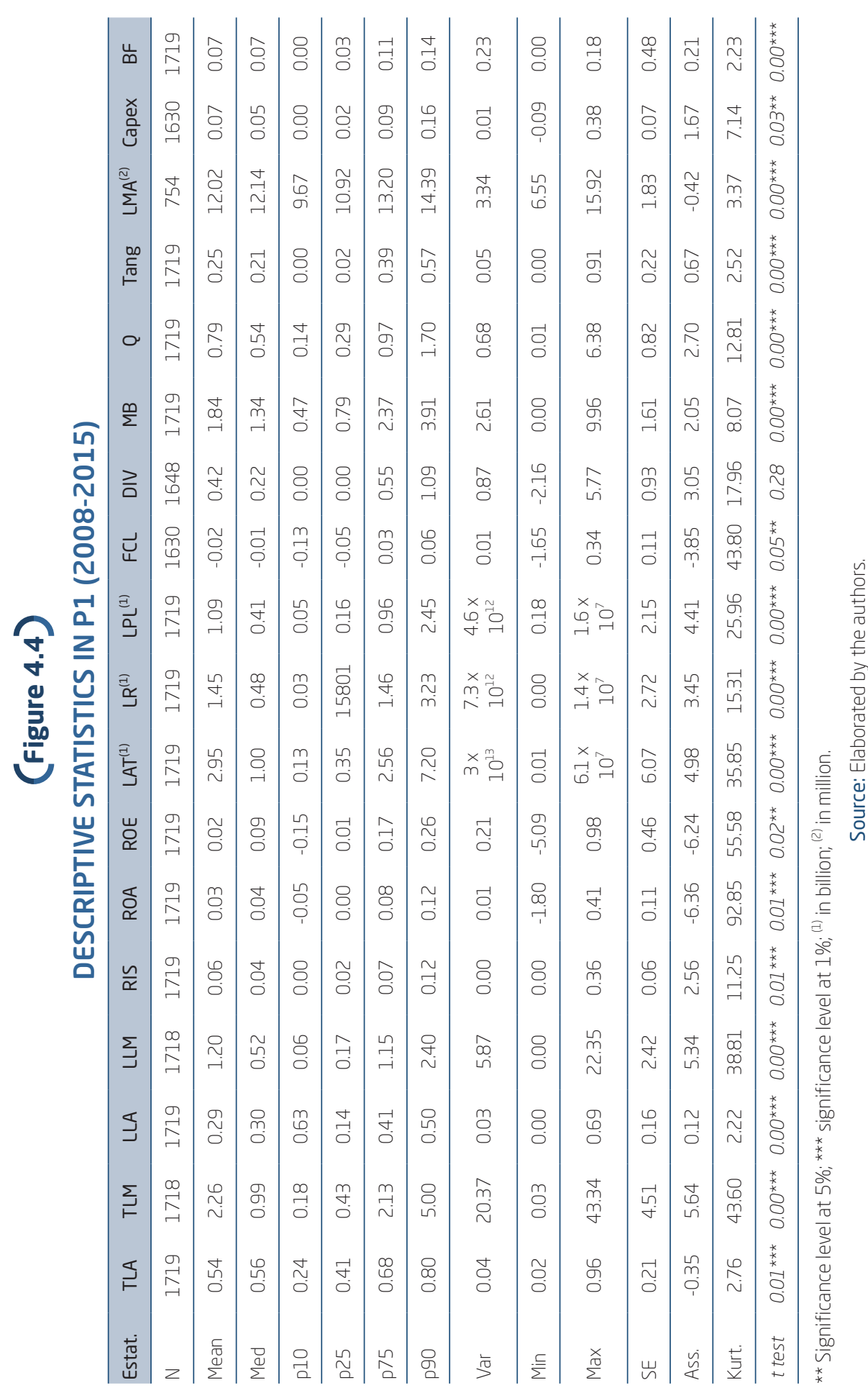


The descriptive statistics of the variables in P1 shows some important differences. In general, the independent variables increased their value over the time, specifically ROE, which became positive (2\%), the total assets, net sales and equity, which increased their values to US $\$ 2.95$ billion, US $\$ 1.45$ billion and US $\$ 1.09$ billion, respectively. The market value increases relating to the book value, both for Tobin's Q and market-to-book. All the variables showed significant statistical differences between samples, with an exception for the variable related with dividends paid.

The leverage measures, TLA and LLA, present similar values when comparing them in the two analyzed periods, while the differences between the means are statistically significant. TLM and LLM declined considerably, TLM specifically was approximately 4.04 in P2, decreasing to 2.26 in the subsequent analyzed period; such behavior is also observed in LLM, which reduced from 1.82 in P2 to 1.20 in P1. As shown in Figure 4.4, the t test evidences that changes in leverage measures are all statistically significant at $1 \%$ confidence level.

The correlation test, presented in Figure 4.5 was run with the objective to identify highly correlated variables. In the existence of co-linearity (strong relation between two or more variables), the use of both variables is not recommended, since they have a similar influence. A significant correlation (above 0.7) has been found between total asset, net income, and equity and between ROA and ROE. To correct this problem, these variables are not used in the same regression.

The third analysis step consists in the estimation of GMM-Sys econometric model. The four measures of leverage (TLM, TLA, LLM, and LLA) are analyzed for each period to verify the behavior of the capital structure during P2 (1995-2007) and P1 (2008-2015) periods. In addition, to compare the analysis, a model with the total period (PG) was estimated, which covers information from 1995 to 2015.

As presented in the bottom of Figure 4.6 , in the chi-square test $\left(\chi^{2}\right)$, the null hypothesis is rejected in the models, indicating an association between groups of variables in the models presented. The Hansen (1982) overidentification test showed that, in all analyses, the null hypothesis is not rejected. It indicates that the instruments are apparently uncorrelated with the error of the regression. Finally, in Arellano and Bond (1991) test [AR(1) and $\mathrm{AR}(2)$ ] the null hypothesis of absence of serial correlation in the residues of the first order is rejected for most of the cases (with exception of the $\mathrm{P} 2$ regressions). However, this result is not observed for the secondorder. The model presents, therefore, serial correlation of first order. For 
Sonza and Kloeckner (2014), it can be considered an important assumption for the instruments' validity based on the lag of the regressors, as the case of dynamic GMM-Sys used in the analysis.

By the argument that the level of financing ratio in the current year is influenced by the previous one, which is confirmed in the analysis below, the four dependent variables used as measures of leverage lagged in one, two and three periods were analyzed. By the significance of leverage lagged, shown in Figure 4.6, it can be observed that the company's financing ratio in the previous year can be considered a determinant in the capital structure; anyway, this influence is short-lived and mainly observed in the first lagged period.

Considering the leverage lagged in one period, if analyzed PG, it is possible to observe positive statistical significance for all measures of leverage, showing that the leverage ratio from the previous year can be considered an important leverage determinant in the current one for TLA and LLA. Additionally, for P1 (2008-2015) the TLM, LLA, and LLM have both shown a statistical relationship with the previous year, which reduces $0.33,0.15$ and 0.35 by one percentage point increase in the previous leverage, both significant at $5 \%$ confidence level. This analysis corroborates the stability observed in the graphical analysis for book measures of leverage behavior, whose characteristic was certain stability over the period and also, the observed TLM and LLM behavior of lower levels of leverage after 2008, as discussed before.

The statistical relationship observed independent variables lagged in one period is not observed if considered the two lagged variables, which has been negatively significant in P1 for TLM and PG for LLA, and for LLA in P2, both at $1 \%$ confidence level. This result shows a short-lived stable behavior and observed only for leverage lagged in one period, furthermore, some signals of stability were found in book measures. This evidence is confirmed by the coefficients of variables lagged in three periods, statistically significant only for TLM and LLM in PG, by a positive relationship of 0.08 and 0.11 percentage points, both at $5 \%$ confidence level. In sum, the analysis of the dependent variables lagged showed influence in the current indebtedness ratio, but mainly when observed one period lag, characterizing a short live stability.

The results show that a one percentage point increase in ROA reduces TLA in 0.27 in PG and 0.50 in P1, respectively, both at $1 \%$ confidence level. When analyzing TLM, an expressive decrease is observed, the increase of one percentage point in return reduces the leverage in 4.83 in PG and 6.09 


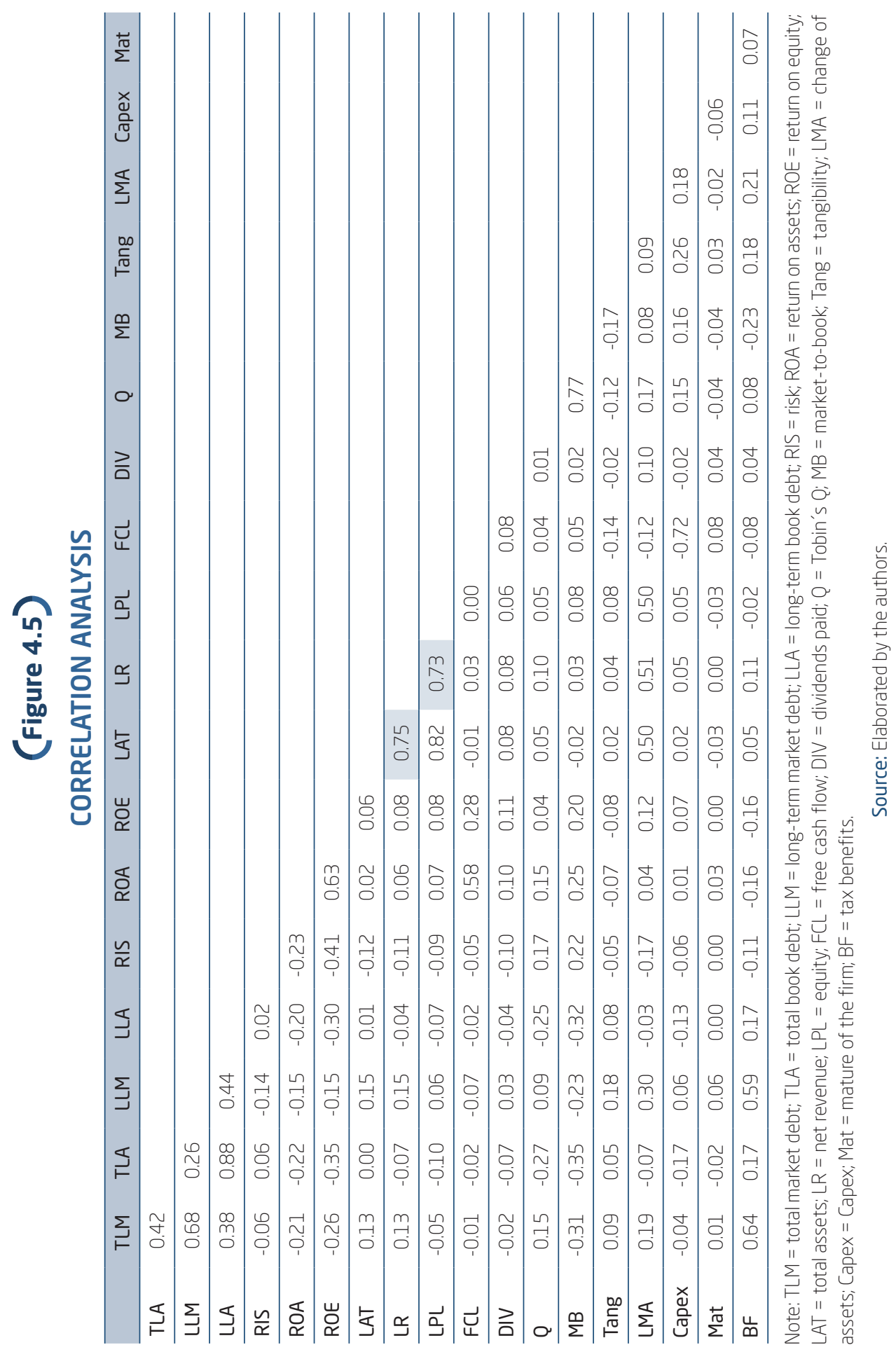


in P1, both statically significant at 5\%. The reduction of debt levels in P1 was expected, in which the companies reduced the leverage considerably in the post-subprime period. For Ferreira and Mattos (2012), firms reduced the supply for credit, followed by higher interest rates and lower attractiveness for foreign investors, corroborating the graphical analysis. Although not significant for LLA, ROA has shown statistical significance in LLM for P2, by a leverage reduction of 8.92 percentage points in response to an increase of ROA. These results are in accordance with the pecking order theory.

The companies size (the logarithm of the total assets) showed a significant positive relationship when analyzed PG for TLA, TLM, and LLM, indicating that, an increase in the size, increase the company's leverage. Similar results were found in TLM, LLA, and LLM for P1. This allows the conclusion that, before the crisis, the size did not matter for the leverage. After this period, the market of credit was reduced, giving preference to bigger firms, which issued more debt, corroborating with the graphical analysis. The expansion of leverage for bigger firms was also found by Taratin Jr, and Valle (2015) results, supporting the trade-off assumptions.

The free cash flow presented a positive relation with leverage; however, it was not statistically significant in most of the analysis, except in TLA for P1 and TLM for PG. The positive relationship between free cash flow and a proxy for profitability is defended by Jensen and Meckling (1976) and Jensen (1986), who state that profitable companies face lower costs of financial distress and enjoy greater tax benefits. Thus, the assumptions presented are consistent with the Trade-off theory assumptions.

The variable related to dividends paid did not show statistical significance in the model analyzed. Tobin's Q considered a measure for growth opportunities, has shown a negative relationship with the market leverage in P1. This result is in compass with the pecking order theory, as stated by Futema, Basso, and Kayo (2009) that, after the crisis, firms with a higher book value in relation to market value were less leveraged. In terms of TLA, this variable was positive and significant for PG.

The change of assets (LMA) had a negative influence on P1 for TLA and TLM. This result indicates that, after the 2008 crisis, a positive change of assets generate a decrease in the leverage, contradicting Frank and Goyal (2009). Risk and tangibility were not statistically significant. Similar results were obtained with Capex, which was positive and significant only for TLA in P1. This finding supports the pecking order argument of Frank and Goyal (2009), who state that capital expenditure increase as leverage increase because they have more resources to finance the investment. 


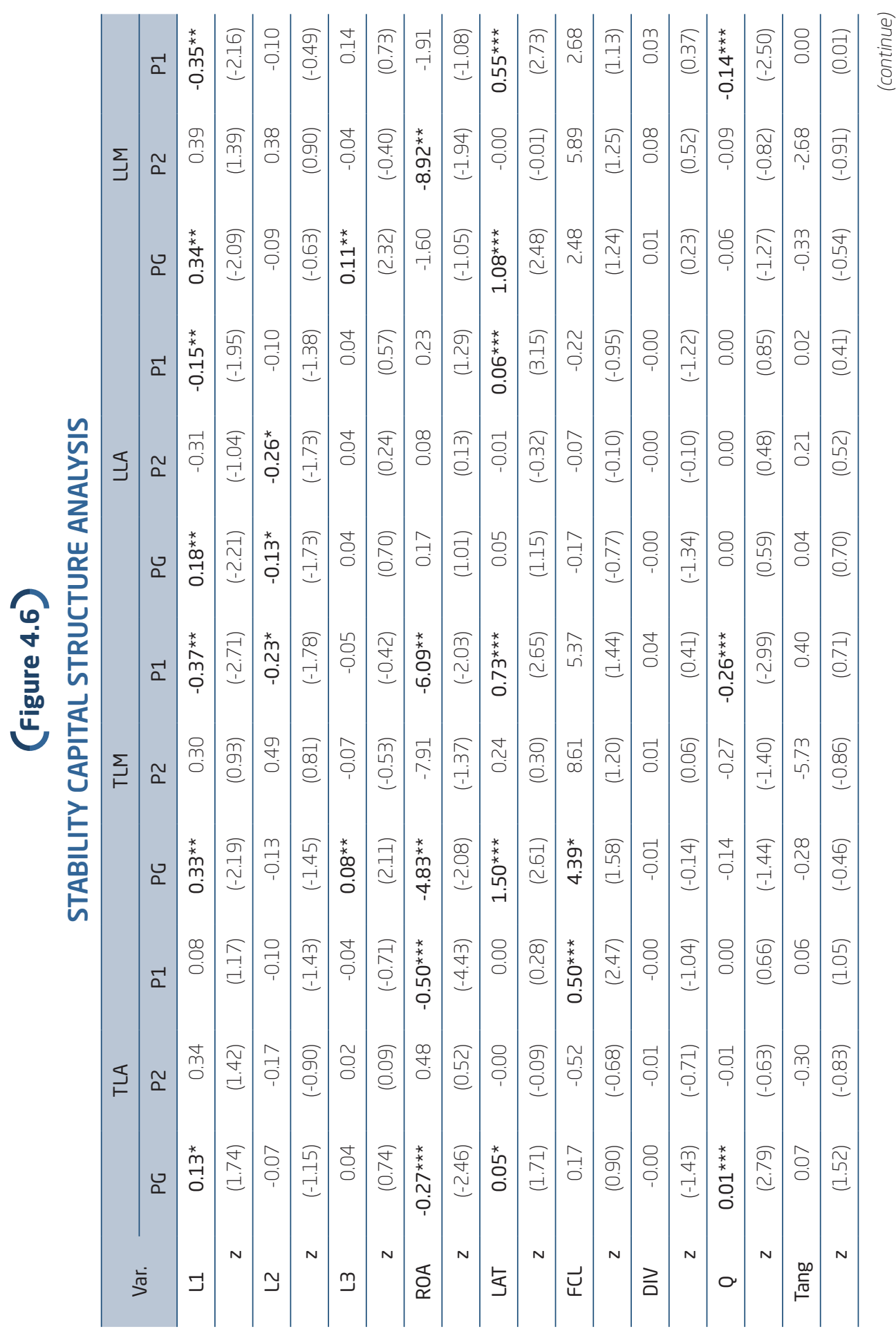




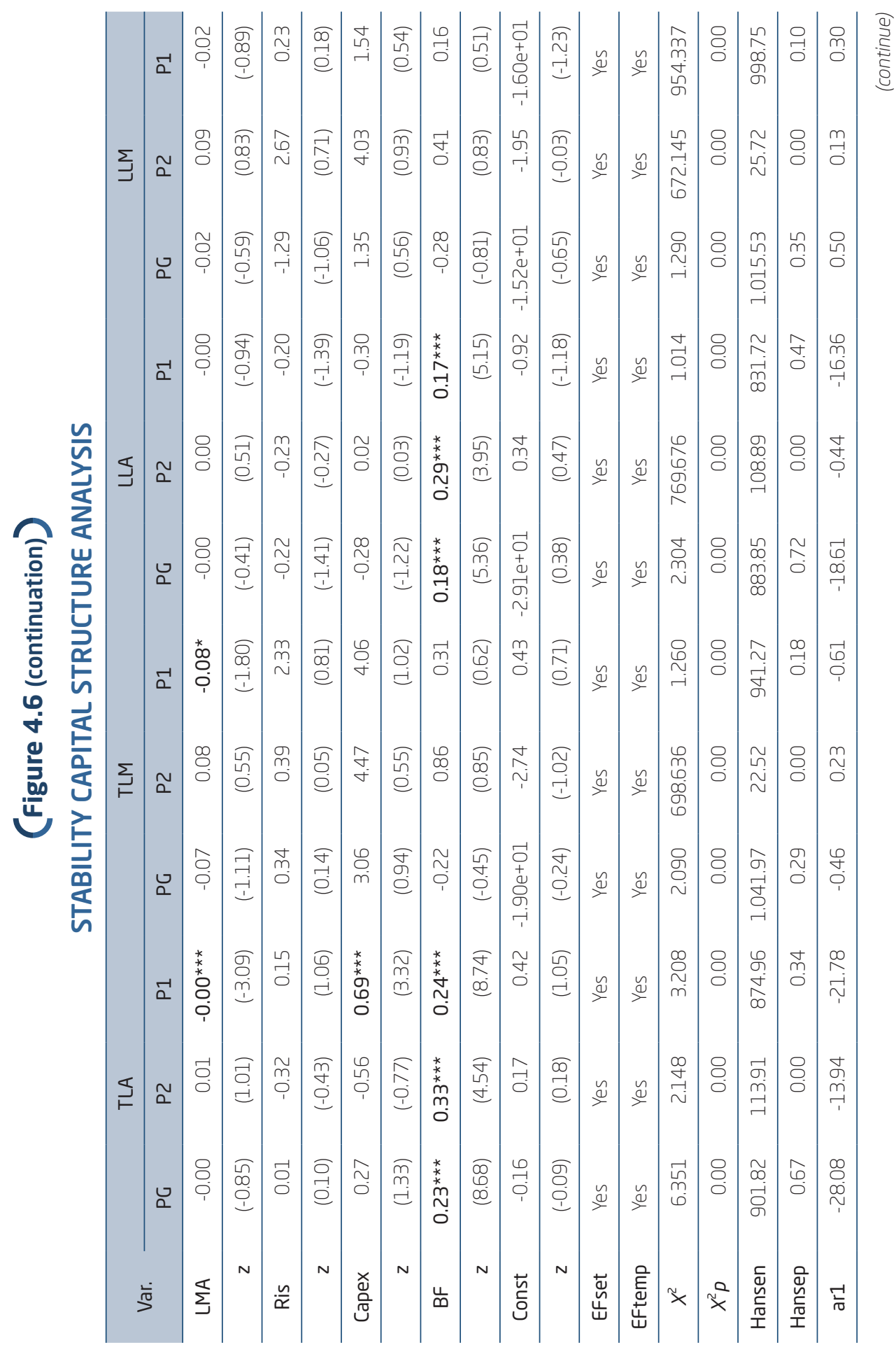




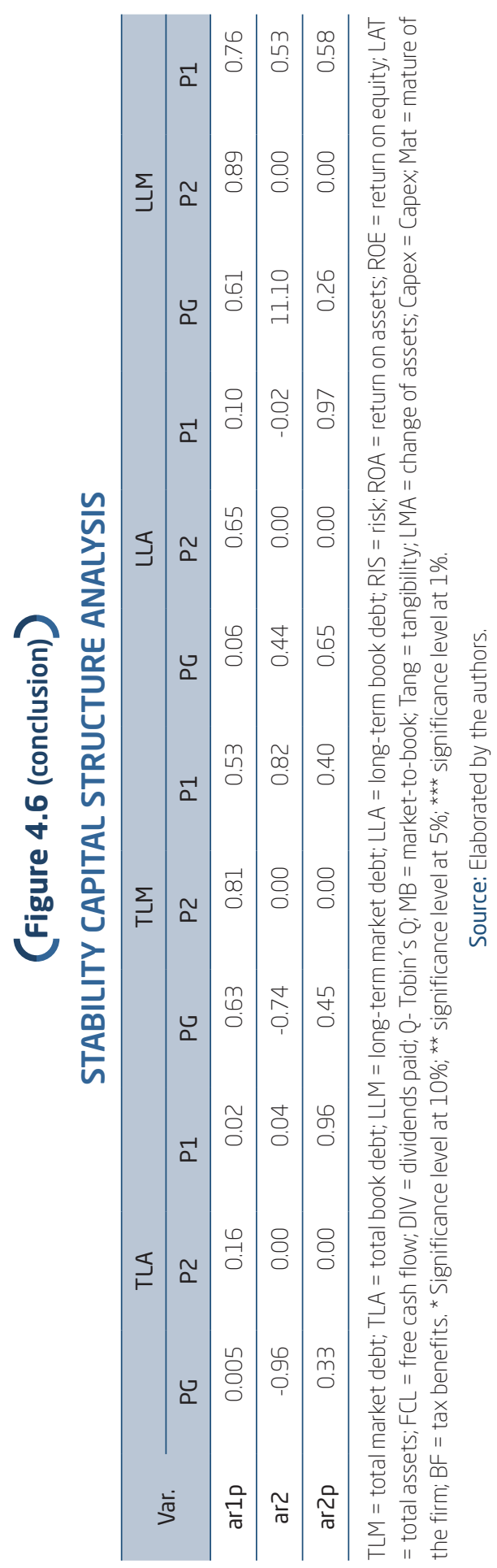


The dummy that represents the Mature Firms (Mat) has been excluded from the model due to its co-linearity; and, finally, the Tax Benefits were positive and significantly related to the leverage in all the regressions associated with book debt, showing that higher the tax benefits a company has, more debt is issued, supporting the trade-off theory stated by Frank and Goyal (2009) and Lemmon et al. (2008). This result corroborates the graphical analysis, where the influence of this variable did not change considerably after and before the crisis.

\section{CONCLUSION REMARKS}

By the fact of being considered one of the most relevant topics in corporate finance, the study about capital structure developed several theories dedicated to investigating the determinants of the companies' leverage. However, none of them has accurately defined the optimal financing policy to be adopted by the companies, leading recent international studies focused on the analysis of the behavior of the capital structure, analyzing their stability over a given period of time.

Based on the most current studies, this research aimed to analyze whether the capital structure of Brazilian companies remained stable in the last 20 years. For this purpose, two samples of Brazilian companies were analyzed over the last 20 years (1995-2015) using the GMM-Sys method. The analysis of groups allowed the comparison of debt ratios between two periods, $\mathrm{P} 2$ and $\mathrm{P} 1$.

Initially, the graphical analysis allowed observing the behavior of the capital structure of the median of companies over the 20 analyzed years. Four measures of leverage were used: total market debt (TLM), total book debt (TLA), long-term market debt (LLM) and long-term book debt (LLA).

In the graphical analysis, the market measures of indebtedness showed an oscillating behavior of leverage during the first years (1995-2007), characterized by the non-stability of corporate debt; this behavior was not observed in the last periods (2008-2015), in which a drastic reduction in debt ratios was observed, maintained until the end of the analyzed period. Contrary, debt variables related to book values showed a lower tendency to move all over the analyzed period, characterizing stability. An explanation about the differences in stability from book leverage to market leverage is called by Welch (2004) as "managerial inertia", who stated that when stock price rises, the market value of equity increases and the market leverage 
decreases, and vice versa. Then, part of the effect of the decrease in market debt ratios can be related to this stock price effect.

As it can be seen in the regression analysis, the results were more significant for the leverage variable lagged one period and relative to P1 (2008-2015), which indicates a significant decrease in the level of leverage. The most statistical significant values were for market leverage (TLM and TLA). This reduction in the second period can also be seen in the long-term book leverage (LLA), indicating, in general, less instability of the capital structure, mainly in the second period.

The econometric model allowed the comparison with other studies carried out in this subject. In general, by the results shown, the hypothesis of stability of the capital structure proposed by Lemmon et al. (2008) is short-lived, as the influence of the dependent variable legged as explanatory of the model was significant only for the first lag in most of the analyzes of $\mathrm{P} 1$. Likewise, the argument that there is a tendency in which companies continuously change their debt levels, proposed by De Angelo and Roll (2015), does not seem adequate, since the second analyzed period partially contradicts the results obtained by them.

The results obtained follow the line of Graham et al. (2015) results, who found stability in the capital structure, followed by an oscillation in debt levels. However, the results obtained in this study showed the opposite, if considered market debt. In the first analyzed period, a strong instability was found, followed by a less unstable behavior in debt levels in the period after 2008. In addition to the observation through graphical analysis, the results were found through the estimation of the model corroborated by these results, through the higher statistically significant relationships found in the second period. The principal determinants of the capital structure in this sample were the tax benefits if considered the book debt; and the size, if considered the market debt, in which the majority of the variables supported the trade-off theory.

The sample is composed of companies traded in B3, which can be considered a limitation, as it presents a bias in the direction for largest Brazilian companies, as well as the results, restricted to the analyzed period. Finally, there is the possibility of endogeneity of the variables. It is also noticed that there are opportunities for future work on the subject, in order to use other methods or period divisions to better capture the data. 


\section{A ESTRUTURA DE CAPITAL NO BRASIL É ESTÁVEL?}

\section{RESUMO}

Objetivo: O objetivo do presente artigo consiste em analisar se a estrutura de capital das empresas listadas publicamente permaneceu estável nos últimos 20 anos.

Originalidade/valor: O artigo tem como foco o mercado de capital brasileiro, no qual existe uma lacuna na literatura acerca de estudos relacionados à alavancagem e sua incipiência, em que fatores relacionados às empresas negociadas abertamente e às características na contratação de capital alteram a demanda por crédito.

Design/metodologia/abordagem: Objetivando o alcance do propósito do estudo, inicialmente foi realizada uma análise gráfica da evolução do endividamento, tanto a valor de mercado quanto contábil; a segunda etapa consistiu na aplicação do modelo econométrico de regressão GMM-Sys por meio de dados em painel para identificar a estabilidade da alavancagem ao longo do tempo.

Resultados: Os resultados evidenciam redução nas medidas de alavancagem a valor de mercado, cuja significância estatística foi observada após 2008 , tem-se, portanto, que, tanto na análise gráfica quanto no modelo de regressão, o uso da dívida apresentou instabilidade no primeiro período analisado (1996-2007). O mesmo comportamento não foi observado no segundo período analisado (2008-2015) ao serem analisadas as medidas a valor de mercado, na qual prevalecia a estabilidade da estrutura de capital. Os achados foram confirmados por meio da estimação do modelo, sendo identificada redução dos níveis de alavancagem com significância estatística das variáveis no segundo período do estudo (P1). Foram encontrados como principais determinantes da estrutura de capital das empresas brasileiras os benefícios fiscais (alavancagem a valor contábil) e o porte da empresa (alavancagem a valor de mercado), confirmando os pressupostos da teoria do trade-off.

\section{PALAVRAS-CHAVE}

Estrutura de capital. Teoria do trade-off. Teoria do pecking order. Endividamento. Estabilidade. 


\section{REFERENCES}

Alti, A. (2005). IPO market timing. The Review of Financial Studies, 18(3), 1105-1138.

Arellano, M., \& Bond, S. (1991). Some tests of specification for panel data: Monte Carlo evidence and an application to employment equations. Review of Economic Studies, 58(2), 277-297.

Axelson, U., Jenkinson, T., Strömberg, P., \& Weisbach, M. S. (2013). Borrow cheap, buy high? The determinants of leverage and pricing in buyouts. The Journal of Finance, 68, 2223-2267. doi:10.1111/jofi.12082

Baker, M., \& Wurgler, J. (2002). Market timing and capital structure. The Journal of Finance, 57(1), 1-32. doi:10.1111/1540-6261.00414

Brito, R. D., \& Lima, M. R. (2005). A escolha da estrutura de capital sob fraca garantia legal: O caso do Brasil. Revista Brasileira de Economia, 59(2), 177-208.

Chung, K. H., \& Pruitt, S. W. (1994). A simple approximation of Tobin's Q. Financial Management, 23(3), 70-74. doi:10.2307/3665623

De Angelo, H., \& Roll, R. (2015). How stable are corporate capital structures? The Journal of Finance, 70(1), 373-418. doi:10.1111/jofi.12163

Denis, D. J. (2012). The persistent puzzle of corporate capital structure: Current challenges and new directions. The Financial Review, 47, 631-643. doi:10.1111/j.1540-6288.2012.00347.x

Devos, E., Rahman, S., \& Tsang, D. (2017). Debt covenants and the speed of capital structure adjustment. Journal of Corporate Finance, 45, 1-18. doi:10. 1016/j.jcorpfin.2017.04.008

Fama, E. F., \& French, K. R. (2002). Testing trade-off and pecking order predictions about dividends and debt. The Review of Financial Studies, 15(1), 1-33. doi:10.1093/rfs/15.1.1

Ferreira, D. M., \& Mattos, L. B. (2012). O efeito contágio da crise do subprime no mercado acionário brasileiro. Encontro Nacional de Economia, Porto de Galinhas, PE, Brasil.

Flannery, M. J., \& Rangan, K. P. (2006). Partial adjustment toward target capital structures. Journal of Financial Economics, 79(3), 469-506.

Frank, M., \& Goyal, V. (2003). Testing the pecking order theory of capital structure. Journal of Financial Economics, 67, 217-248. 
Frank, M., \& Goyal, V. (2009). Capital structure decisions: Which factors are reliably important? Financial Management, 38(1), 1-37.

Futema, M. S., Basso, L. F., \& Kayo, E. K. (2009). Estrutura de capital, dividendos e juros sobre o capital próprio: testes no Brasil. Revista Contabilidade E Finanças-USP, 20(49), 44-62. doi:10.1590/S1519-7077 2009000100004

Graham, J., Harvey, C., \& Puri, M. (2009). Managerial attitudes and corporate actions. Duke University. doi:10.1016/j.jfineco.2013.01.010i

Graham, J. R., Leary, M. T., \& Roberts, M. R. (2015). A century of capital structure: The leveraging of corporate America. Journal of Financial Economics, 118(3), 658-683. doi:10.1016/j.jfineco.2014.08.005

Hansen, L. P. (1982). Large sample properties of generalized method of moments estimators. Econometrica, 50(4), 1029-1054.

Hennessy, C. A., Livdan, D., \& Miranda, B. (2010). Repeated signaling and firm dynamics. The Review of Financial Studies, 23(5), 1981-2023. doi:10.10 93/rfs/hhq004

Iquiapaza, R. A., Souza, A. A. D., \& Amaral, H. F. (2007). Capital structure and financing decisions: New test for pecking order theory. Working Paper SSRN. doi:10.1590/S1678-69712008000300008

Jensen, M. C. (1986). Agency costs of free cash flow, corporate finance, and takeovers. The American Economic Review, 76(2), 323-329.

Jensen, M. C., \& Meckling, W. (1976). Theory of the firm: Managerial behavior, agency costs and ownership structure. Journal of Financial Economics, 3(4), 305-360.

Kayhan, A., \& Titman, S. (2007). Firms' histories and their capital structures. Journal of Financial Economics, 83(1), 1-32. doi:10.3386/w10526

Keefe, M. O., \& Yaghoubi, M. (2016). The influence of cash flow volatility on capital structure and the use of debt of different maturities. Journal of Corporate Finance, 38, 18-36. doi:10.1016/j.jcorpfin.2016.03.001

Kieschnick, R., \& Moussawi, R. (2018). Firm age, corporate governance, and capital structure choices. Journal of Corporate Finance, 48, 597-614. doi:10.1016/j.jcorpfin.2017.12.011

Kim, W. S., \& Sorensen, E. H. (1986). Evidence on the impact of the agency costs of debt on corporate debt policy. Journal of Financial Quantitative Analysis, 21(2), 131-144. doi:10.2307/2330733

Kraus, A., \& Litzenberger, R. H. (1973). A state-preference model of optimal financial leverage. The Journal of Finance, 28(4), 911-922. doi:10.1111/j.15 40-6261.1973.tb01415.x 
Leary, M. T., \& Roberts, M. R. (2005). Do firms rebalance their capital structures? The Journal of Finance, 60(6), 2575-2619. doi:10.1111/j.15406261.2005.00811.x

Lemmon, M. T., Roberts, M., \& Zender, J. F. (2008). Back to the beginning: Persistence and the cross-section of corporate capital structure. The Journal of Finance, 63, 1-37.

Malmendier, U., Tate, G., \& Yan, J. (2011). Overconfidence and early-life experiences: The effect of managerial traits on corporate financial policies. The Journal of Finance, 66(5), 1687-1733. doi:10.1111/j.1540-6261.2011. 01685.x

Medeiros, O. R., \& Daher, C. E. (2008). Testando teorias alternativas sobre a estrutura de capital nas empresas brasileiras. Revista de Administração Contemporânea, 12(1), 177-199. doi:10.1590/S1415-65552008000100009

Modigliani, F., \& Miller, M. (1958). The cost of capital, corporate finance and the theory of investment. The American Economic Review, 48(3) 261-297.

Modigliani, F., \& Miller, M. (1963). Corporate income taxes and the cost of capital: A correction. The American Economic Review, 53(3), 433-443.

Myers, S. (1984). The capital structure puzzle. The Journal of Finance, 39(3), 575-592.

Myers, S., \& Majluf, N. (1984). Corporate financing and investment decisions when firms have information that investors do not have. Journal of Financial Economics, 13(2), 187-221.

Nakamura, W. T., Martin, D. M. L., \& Forte, D. (2007). Determinantes de estrutura de capital no mercado brasileiro: Análise de regressão com dados longitudinais no período 1999-2003. Revista de Contabilidade E Finanças, 18(44), 72-85.

Ozkan, A. (2001). Determinants of capital structure and adjustment to long run target: Evidence from UK company panel data. Journal of Business \& Accounting, 28(1-2).

Serrasqueiro, Z., \& Caetano, A. (2015). Trade-off theory versus pecking order theory: Capital structure decisions in a peripheral region of Portugal. Journal of Business Economics and Management, 16(2), 445-466. doi:10.3846/ 16111699.2012.744344

Shyam-Sunder, L., \& Myers, S. C. (1999). Testing static tradeoff against pecking order models of capital structure1. Journal of Financial Economics, $51(2), 219-244$. 
Sonza, I. B., \& Kloeckner, G. O. (2014). Governança em estruturas proprietárias concentradas: Novas evidências para o Brasil. Revista de Administração, $49(2), 240-250$.

Tarantin, W. T., Junior, \& Valle, M. R. do (2015). Estrutura de capital: O papel das fontes de financiamento nas quais companhias abertas brasileiras se baseiam. Revista Contabilidade \& Finanças-USP, 26(69), 331-344. doi:10.1590/1808-057x201512130

Titman, S., \& Wessels, R. (1988). The determinants of capital structure choice. The Journal of Finance, 43 (1), 1-19. doi:10.2307/2328319

Welch, I. (2004). Capital structure and stock returns. Journal of Political Economy, 112(1), 106-131.

\section{AUTHOR NOTES}

Pâmela A. Tristão, Graduate Program in Business Administration at Universidade Federal de Santa Maria (UFSM); \& Igor B. Sonza, Graduate Program in Business Administration at Universidade Federal do Rio Grande do Sul (UFRGS).

Pâmela A. Tristão is PhD in Business Administration by Universidade Federal de Santa Maria (UFSM); \& Igor B. Sonza is now professor at Graduate Program in Business Administration at Universidade Federal de Santa Maria (UFSM).

Correspondence concerning this article should be addressed to Pâmela A. Tristão, Avenida Roraima, 1.000, Camobi, Santa Maria, Rio Grande do Sul, Brazil, CEP 97105-900.

E-mail: pamelamado@hotmail.com

EDITORIAL BOARD

Editors-in-chief

Janette Brunstein

Silvia Marcia Russi de Domênico

Associated Editor

Michele Jucá

Technical Support

Vitória Batista Santos Silva

\section{EDITORIAL PRODUCTION}

Publishing Coordination

Jéssica Dametta

Layout Designer

Language Editor

Daniel de Almeida Leão

Emap

Graphic Designer

Libro 